\title{
Impact of microwave-grill-drying (mwgd) on functional properties of berry russian olive (Elaeagnus angustifolia L.)
}

\author{
Soussene Boudraa ${ }^{1, *}$ \\ http://orcid.org/0000-0002-8809-0084
}

${ }^{1}$ Food Science Laboratory (LSA), Department of Food Engineering, Veterinary and Agriculture Institute, University Hadj Lakhdar Batna, Algeria.

*Correspondence: b_sawsen82@yahoo.fr

Received: 2019.07.09; Revised: 2019.11.12; Accepted: 2019.12.07; Published: 2020.01.01

Highlights: The paper addresses the "Impact of microwave-grill-drying (MWGD) at different powers (300, 450 and 600 Watts) on functional properties of berry "Russian olive". The microwave grill have potential use in food and pharma products.

Section: This paper was submitted in Food technology, a section of the J. Bioen Food Sci.

Competing interests: There is not conflict of interest in the research conducted.

Funding: The author received no specific funding for this work.

Citation as (APA): Boudraa, S, (2020). Impact of microwave-grill-drying (MWGD) on functional properties of berry Russian olive (Elaeagnus angustifolia L.). Journal of bioenergy and food science, 7(1), e2752019JBFS. doi: 10.18067/jbfs.v7i1.275

Edited by Dr. Victor Hugo Gomes Sales - Federal Institute of Amapá, Macapá-AP, Brazil.

Review processes: 2752019R01 | 2752019R03

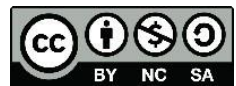

JBFS all rights Copyright: @ 2020

\begin{abstract}
Impact of microwave-grill-drying (MWGD) at different powers (300, 450 and 600 Watts) on functional properties of berry "Russian olive» was investigated. The effect of microwave water and oil holding capacities, gelation, foaming and emulsifying, which will provide novel and applicable knowledge for the food industry, was determined. We specifically focused the kinetics drying by increasing microwave-grill powers $(300,450 \mathrm{~W}$ and $600 \mathrm{~W})$, drying time decreased from 270 to 120s. For dried Russian olive berry at each applied microwave-grill power, water holding capacity values were higher than oil holding capacity values. However, drying at $450 \mathrm{~W}$ is the best method of retention of functional properties of fresh fruit of $E$. angustifolia $L$.
\end{abstract}

Keywords: Russian olive. Fruit. Power. Microwave-grill. Kinetics drying. Functional properties. 


\section{INTRODUCTION}

Oleaster (Elaeagnus angustifolia L.) is a tree, and its fruit grows in various climatic and environmental conditions. It is also known as Russian olive and native to western and central Asia, from southern Russia and Kazakhstan to the Mediterranean environment (Çakmakçı, 2014).

The main Elaeagnus species in Algeria, Russian olive (Elaeagnus angustifolia L.), commonly called "Jijibe", grows spontaneously and it is located mainly in the highlands. It was introduced and planted in the regions of Djelfa, Biskra, Relizane, Mascara and South Tennes and Cherchell (Journal of Agriculture \& le Botanique Appliquée, 1958).

Fruits are valuable in terms of health and can be used as natural antioxidants (Durmaz, 2012), and for their natural color. Also as used in the fields of medicine and pharmacy and in Asiaand in Europe is certified (Çakmakçı, 2014).

There are no toxic substances in oleaster fruits. Oleasteris advised to be consumed by the people who have kidney disorders. It can be used as a diuretic and fever-reducing drug (Baytop, 1984), for preventing intestinedisorders and mouth rust, and its fruit extracts can be used as antiinflammatory and analgesic (Ahmediani et al., 2000) in traditional medicine. The oleaster fruitcontains $12.33 \%$ protein (Akbolat et al., 2008), vitamins (tocopherol, carotene, vitamin C, and thiamine), mineral substances (calcium, magnesium, potassium, iron, and manganese) in Boudraa et al., 2010). Dominant sugars are in the plant fructose and glucose (Ayaz \& Bertoft, 2001). The size of the fruit is the same as olives and skin is hard, yellowish-brown in color (Çakmakçı et al., 2014).

Drying is the oldest and most popular preservation method for food and agricultural products. The fundamental concept of drying is to trim down moisture of products to a level, which will stop microbiological growth and keep the product's nutritive value and bioactive compounds in considerably higher levels (Kwok et al., 2004; Changrue, 2006). Several drying methods have been developed in order to preserve different kinds of food materials because of myriad environmental, energy efficiency and economic concerns. Besides, all methods have something in common; the heat is applied by conduction, convection, radiation.

In order to prevent quality damage due to long drying time, microwave grill drying has been introduced (Movagharnejad et al., 2019). Microwave heating is a sort of dielectric heating, which uses electromagnetic radiation in the frequency ranging from $300 \mathrm{MHz}$ to $300 \mathrm{GHz}$. According to Changrue (2006), the decrement of drying time due to volumetric heating of dielectric material increase the use of the microwave as a source of thermal energy.

Although studies have focused on the drying kinetics of Elaeagnus angustifolia L., the lack of published work on the effect of microwave grill drying at levels power on functional properties (protein solubility, water and oil absorption capacity, emulsifying and foaming properties, density, viscosity and gelation) of Russian olive explains the interest for the present work.

\section{MATERIAL AND METHODS}

\section{a) Fruit collections}

Healthy mature hawthorn (Elaeagnus angustifolia L.) fruits were harvested between October-November (2018) in North-West Algeria. Russian olive had an initial moisture content of percentage-wet basis, which was determined by drying in a convective oven (Memmert DO 6836, Germany) at $103 \pm 1{ }^{\circ} \mathrm{C}$ for $24 \mathrm{~h}$ (Anon, 1995). The fruit was conserved at $-20{ }^{\circ} \mathrm{C}$ until used. Russian olive was sorted. After that, the total quantity was divided into three batches, one for each process Microwave grill drying.

\section{b) Drying Methods}

\section{Microwave- grill drying}

The drying apparatus used consisted of a laboratory microwave grill oven (GE107Y, SAMSUNG Electronics) with technical features of $230 \mathrm{~V}, 50 \mathrm{~Hz}$ with a frequency of $2,450 \mathrm{MHz}$. 
The dimension of the microwave cavity was $335 \mathrm{~mm} \times 330 \mathrm{~mm} \times 195 \mathrm{~mm}$. Drying trials were carried out at different microwave generation powers 300, 450 and 600W. Drying was performer per cycle (30 s ON / $30 \mathrm{~s}$ OFF); each cycle corresponds to the application of microwaves for a given $30 \mathrm{~s}$ power and $30 \mathrm{~s}$ power off. We took three glass capsules, previously cleaned and dried, the pulp of Russian olive. The capsules containing the samples are then placed in the microwave and for the study of the drying kinetics by this system; six different powers were used $(100,180$, $300,450,600$ and $900 \mathrm{~W}$ ). After $30 \mathrm{~s}$ of drying, the capsules are removed from the microwave and placed in a desiccator to cool them down. Then weighed each sample with a precision balance of $0.001 \mathrm{~g}$ (model: GL-300). This operation is repeated regularly for each 30 second interval.

Until a constant weight of three successive cycles is obtained. During the drying process, we followed the evolution of the loss of mass of the products and thus established the drying kinetics. The drying kinetics was thus determined by the evolution of the mass of the products after each cycle.

Drying was run until the moisture content of about $10 \%$ w.b. the water was attained; the Mass of the material was recorded continuously during drying with the accuracy $\pm 0.1 \mathrm{~g}$. By the equation below it can be determined the variation of the dry base moisture content $(\mathrm{X})$ versus time (s).

$$
X=(W w-W d) / W d
$$

Were:

X: Moisture content on a dry basis $\left(\mathrm{kg} \mathrm{H}_{2} \mathrm{O} / \mathrm{kg}\right.$ dry matter)

Ww: Weight of the sample on a wet basis $(\mathrm{g})$

Wd: Weight of dry matter of the sample $(\mathrm{g})$

Russian olive was placed inside the MWGD oven. For all the power levels studied, samples $(5 \pm 0.5 \mathrm{~g}$ ) were taken from the MWGD oven every $120 \mathrm{~s}$ for $600 \mathrm{~W}$, up to $180 \mathrm{~s}$ for $450 \mathrm{~W}$, and up to 270 s for $300 \mathrm{~W}$. The total drying time was determined as the passing time until no discernible weight change for each sample was observed in each MWGD power level.

Given the heterogeneity of the microwave heating, we realized the average of ten repetitions for each power.

The Drying process was performed in three independent repetitions. The fruit was kept at $-20^{\circ} \mathrm{C}$ and ready for further analysis.

\section{c) Functional properties analyses}

\section{Water and oil absorption capacity}

Measurements of water and oil retention capacity are performed according to the method of Phillips et al. (1988). One gram of the dried Russian olive is mixed $\left(\mathrm{m}_{0}\right)$ in $10 \mathrm{ml}$ of water or oil and the whole was mechanically stirred for 30 min using a stirrer. The mixture was then centrifuged at $4500 \mathrm{rpm} / \mathrm{min}$ for $30 \mathrm{~min}$ in a centrifuge (SIGMA 3K20). The pellet after centrifugation is weighed $\left(m_{1}\right)$, but for measuring the water retention capacity, it is first dried at $105^{\circ} \mathrm{C}$ an oven for $8 \mathrm{~h}\left(\mathrm{~m}_{2}\right)$. The water retention capacity (WAC) and oil retention capacity (OAC) is calculated by the following formulas:

$$
\begin{aligned}
& W A C(\%)=(m 2-m 1) / m 1 \times 100 \\
& O A C(\%)=(m 1-m 0) / m 0 \times 100
\end{aligned}
$$

Were:

WAC is water retention capacity ( $\mathrm{g}$ water / $100 \mathrm{~g}$ materials).

$\mathrm{OAC}$ is oil retention capacity(g oil / $100 \mathrm{~g}$ materials).

\section{d) Solubility properties}

One hundred micrograms $(0.1 \mathrm{~g})$ of the dried Russian olives were placed into a centrifuge tube (known weight) then dissolved with $10 \mathrm{ml}$ of $1 \%$ acetic acid for 30 min, using an incubator shaker operating at $240 \mathrm{rpm}$ and $25^{\circ} \mathrm{C}$. The solution was then immersed in a boiling water bath for 
$10 \mathrm{~min}$, cooled to room temperature $25{ }^{\circ} \mathrm{C}$ and centrifuged at $10.000 \mathrm{rpm}$ for $10 \mathrm{~min}$. The supernatant was decanted. The undissolved particles were washed in distilled water $(25 \mathrm{~mL})$ then centrifuged at $10.000 \mathrm{rpm}$. The supernatant was removed and undissolved pellets dried at $60{ }^{\circ} \mathrm{C}$ for $24 \mathrm{hr}$. Finally, weighed the particles and determined the percentage solubility (Fernandez-Kim, 2004). Calculation:

$$
\text { Solubility }(\%)=(i w-f w) / i w \times 100
$$

Were:

iw: Initial weight of the sample $(\mathrm{g})$

fw: Final weight of the sample $(\mathrm{g})$

\section{e) Emulsion activity (EA) and emulsion stability (ES)}

Emulsifying activity and stability were determined using the method of Neto et al. (2001). Five milliliters portion of dried Russian olive dispersion in water $(10 \mathrm{mg} / \cdot \mathrm{mL})$ was homogenized with $5 \mathrm{~mL}$ oilfor $1 \mathrm{~min}$. The emulsions were centrifuged at $1100 \mathrm{~g}$ for $5 \mathrm{~min}$. The height of emulsified layer and that of the total contents in the tube was measured. The emulsifying activity (EA) was calculated as:

$$
E A(\%)=h 1 / h 2 \times 100
$$

Were:

$h_{1}$ is height of emulsified layer the tube $(\mathrm{mL})$

$h_{2}$ is height of the total content the tube $(\mathrm{mL})$

Emulsion stability (ES) was measured by re-centrifugation followed by heating at $80^{\circ} \mathrm{C}$ for 30 minutes and subsequently cooled to $15^{\circ} \mathrm{C}$. After centrifugation, the emulsified poured into $50 \mathrm{~mL}$ measuring cylinders and stay a few minutes until the emulsified layer was stable. ES was expressed as the percent of the total volume remaining emulsified after heating.

$$
E S(\%)=h 1 / h 2
$$

Were:

$\mathrm{h}_{1}$ isheight of emulsified layer heating $(\mathrm{mL})$

$\mathrm{h}_{2}$ isheight of emulsified layer before heating $(\mathrm{mL})$

\section{f) Foaming properties}

Foam capacity (FC) and foam stability (FS)

The method of Coffman and Garcia (1977) is used for the determination of the foaming capacity and stability of dried Russian olive. A weighed amount of flour is dispersed in $100 \mathrm{ml}$ distilled water, after which the suspension was whipped vigorously for 2 min using a Philips HR2052/91 kitchen blender set at speed 2. Volumes were recorded before and after whipping. FC was expressed as the percentage increase in volume. After $30 \mathrm{~min}$, the volume of foam was measured and expressed as FS.

$$
F C=[(V 1-V 2) / V 2] \times 100
$$

Were:

$\mathrm{V}_{1}$ is Volume after whipping $(\mathrm{mL})$

$V_{2}$ is volume before whipping $(\mathrm{mL})$

$$
F S=(\text { Foam volume after time }(t) / \text { Initial foam volume }) \times 100
$$




\section{g) Viscosity}

Rheology studies the phenomena of deformation and flow of solids and fluids under the influence of mechanical forces. Viscosity characterizes resistance to flow.

Viscosities of fresh, dried fruit extracts were determined using a Gemini 150 digital Rheometer; three pascal-second reads ( $\mathrm{mPa} . \mathrm{s})$ were taken per sample and recorded on the computer.

h) $\mathrm{pH}$

One gram of the dried Russian olive is homogenized in $3 \mathrm{ml}$ of distilled water. The $\mathrm{pH}$ of the solution obtained was determined using a $\mathrm{pH}$-meter (Model: HANNA HI 2210) in according the method AFNOR NF V 50-108 (AFNOR, 1982).

\section{i) Total soluble solids (TSS)}

The percentage of soluble solids is determined using a refractometer. The separation limit, between the light and dark areas on the scale of the refractometer, indicates the refractive magnitude of the light, which is a function of the percentage of soluble dry matter contained in the extracts, called refractive index (IR) (Refracto 30PX) or Brix degree in according the method AFNOR NF V 50-109 (AFNOR, 1982).

\section{i) Gelation properties}

Gelation properties were studied by employing the method of Coffman \& Garcia (1977). Sample suspensions of $2-20 \%$ were prepared in distilled water. Ten milliliters of each of the prepared dispersions was transferred into a test tube. The test tubes were heated in a boiling water bath for $1 \mathrm{~h}$, after which they were cooled in a bath of cold water. The test tubes were further cooled at $4^{\circ} \mathrm{C}$ for $2 \mathrm{hr}$. The least gelation concentration was taken as the concentration when the sample from an inverted test tube did not fall or slip.

$$
\text { Gelationproperties }=(h 1 / h 2) \times 100
$$

Were:

$\mathrm{h}_{1}$ is height of gelation layer in the tube $(\mathrm{mL})$

$\mathrm{h}_{2}$ is height of the total content in the tube $(\mathrm{mL})$

\section{j) Statistical analysis}

The experimental data were expressed as means \pm standard deviations. All determinations were carried out in triplicates. A statistical analysis of the results was performed using the 2009 XLStat software. An equal average hypothesis was tested by analysis of variance (ANOVA). The means was significantly different when compared with the method of Newman-Keuls $(p \leq 0.05)$.

\section{RESULTS AND DISCUSSION}

\section{a) Moisture}

The moisture content change between 15.20 and $23.14 \%$ for fruits. These results were similar to dried fruits, such as fig (30.00\%), prune (30.92\%), cranberry $(16.00 \%)$ and apricot $(30.89 \%)$ (Cansev et al., 2011). This low water content results in the low water activity and low of biochemical and microbiological chemical alterations. These fruits have the advantage of being easily preserved, so they can be consumed for several months and thus be used for industrial purposes.

\section{b) Drying Kinetics}

Microwave grill drying Kinetics 
The variations of the water content $(X)$ versus time $(s)$ for three powers of the microwave grill oven are shown in Figure 1.

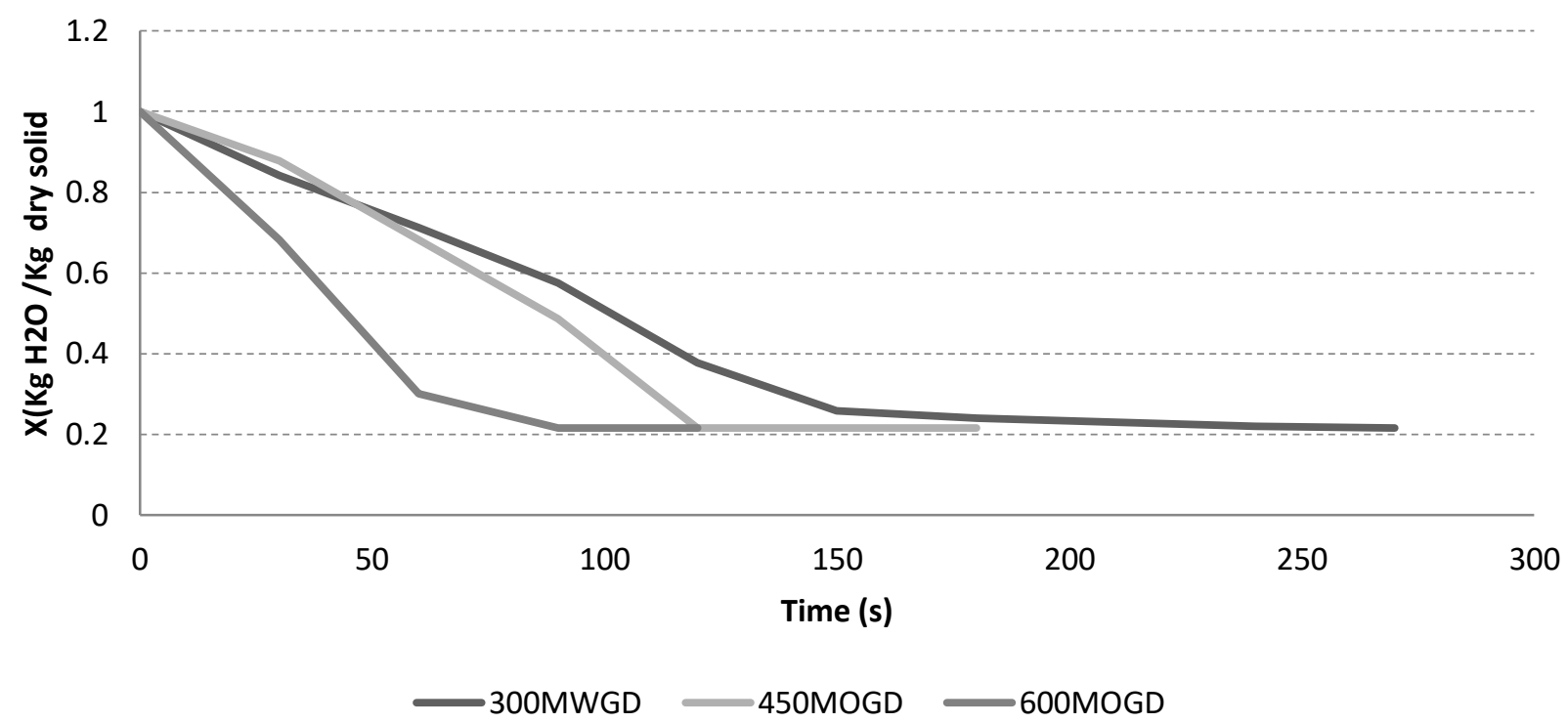

Figure 1 Variation in moisture content $\mathrm{X}\left(\mathrm{kg} \mathrm{H}_{2} \mathrm{O} / \mathrm{kg}\right.$ dry matter) versus time (s) of dried Russian olive in microwave grill at different power.

Overall we see regularly decreasing curves (Figure1), this is due to the high evaporation of water free of all samples.

The drying time is reduced with increasing power and energy delivered by the microwave grill. The power of $600 \mathrm{~W}$ showed the shortest time (120 s).

Obviously, drying time reduced with the increasing microwave drying power levels from $300 \mathrm{~W}$ to $450 \mathrm{~W}$ and lastly to $600 \mathrm{~W}$. Based on Figure1, the time required to reduce the moisture content of the Russian olive stem from $1 \mathrm{~kg} \mathrm{H} \mathrm{H}_{2} \mathrm{O} / \mathrm{kg}$ dry solid to $0.2 \mathrm{~kg} \mathrm{H} \mathrm{H}_{2} \mathrm{O} / \mathrm{kg}$ dry solid varied between $120 \mathrm{~s}$ to $270 \mathrm{~s}$ subjected to the microwave grill power level.

In the beginning, the water content is important, which results in an acceleration of evaporation of water under the heating of the samples by the microwave rays and convection.

The observed drastic or sudden drying curve at the initial stages of microwave drying may be triggered by the opening of the sample's structure physically which allowing rapid vaporization and passage of water molecules (Kostaropoulos \& Saravacos, 1995).

\section{c) Effect microwave-grill drying on the functional properties of Russian olive pulp}

Water and oil absorption capacity

Water and oil absorption capacity are very important in the food system because of their effects on the flavor and texture of foods (Amadou et al., 2010; Kisambira et al.,2015). As shown in Table 1.

Table1. Effect of microwave-grill drying at different powers on the water and oil absorption capacity, solubility, emulsifying capacity, emulsion stability, foaming power, viscosity, $\mathrm{pH}$ and total soluble solidof Russian olive.

\begin{tabular}{|c|c|c|c|c|c|c|c|c|c|}
\hline Methods & $\begin{array}{l}\text { WAC } \\
(\%)\end{array}$ & $\begin{array}{l}\text { OAC } \\
(\%)\end{array}$ & $\begin{array}{c}\text { Solubility } \\
(\%)\end{array}$ & $\begin{array}{l}\text { EA } \\
(\%)\end{array}$ & $\begin{array}{l}\text { ES } \\
(\%)\end{array}$ & $\begin{array}{l}\mathrm{FC} \\
(\%)\end{array}$ & $\begin{array}{l}\text { Viscosity } \\
\text { (mPa.s) }\end{array}$ & $\mathrm{pH}$ & $\begin{array}{c}\text { TSS } \\
{\left[{ }^{\circ} \text { Brix }\right]}\end{array}$ \\
\hline \multicolumn{10}{|c|}{ Drying methods } \\
\hline $\begin{array}{c}\text { Fresh } \\
\text { fruit }\end{array}$ & $220.93 \pm 0.93^{c}$ & $160 \pm 0.40^{c}$ & $89 \pm 3.00^{\mathrm{a}}$ & $43.47 \pm 1.04^{b}$ & $83.33 \pm 2.0^{\mathrm{a}}$ & 0 & $2.45 \pm 0.0^{a}$ & $5.23 \pm 0.0^{a}$ & $42 \pm 5.0^{a}$ \\
\hline \multicolumn{10}{|c|}{ Microwave grill drying } \\
\hline $300 \mathrm{~W}$ & $203.06 \pm 6,0^{d}$ & $201.03 \pm 5.1^{\mathrm{a}}$ & $61 \pm 0.30^{c}$ & $42.38 \pm 0.04^{b}$ & $64.61 \pm 0.01^{\mathrm{c}}$ & 0 & $1.17 \pm 0.0^{d}$ & $5.22 \pm 0.0^{\mathrm{a}}$ & $2.4 \pm 0.0^{d}$ \\
\hline $450 \mathrm{~W}$ & $236.12 \pm 0.3^{b}$ & $165.22 \pm 1.0^{\mathrm{b}}$ & $66 \pm 0.11^{\mathrm{a}}$ & $62.32 \pm 0.01^{a}$ & $76.32 \pm 0.00^{b}$ & 0 & $1.45 \pm 0.0^{\mathrm{b}}$ & $5.22 \pm 0.0^{\mathrm{b}}$ & $4.9 \pm 0.0^{b}$ \\
\hline $600 \mathrm{~W}$ & $256.23 \pm 5.0^{\mathrm{a}}$ & $130.13 \pm 0.0^{d}$ & $52 \pm 3.00^{d}$ & $30.33 \pm 0.02^{c}$ & $60.00 \pm 0.09^{d}$ & 0 & $1.29 \pm 0.0^{c}$ & $5.21 \pm 0.0^{\mathrm{b}}$ & $3.5 \pm 0.0^{c}$ \\
\hline
\end{tabular}

a, b, c, d: In each column, means followed by a different letter are significantly different at the threshold of $p<0.05$ (Method of Newman and Keuls). 
The water and oil absorption capacity of the Russian olives samples ranged $(203.06 \pm 6.00 \%$ and $256.23 \pm 5.00 \%$, microwaved grill at 300 and 600 W. Subjection of Russian olives to microwave reduced the water and oil capacity. Water absorption capacity is relevant in ensuring that food products possess good texture, which invariably reduces retrogradation and syneresis during storage, retorting and freezing (Odedeji \& Adeleke, 2010). Oil absorption capacity is useful in food preparations that involve like bakery products where oil is an important ingredient (PrincewillOgbonna \& Ezembaukwu, 2015).

Robertson \& Eastwood (1981) suggested that WAC is considered to be a function of fiber structure rather than a chemical composition. The power levels of microwave grill drying were reported to affect the fiber structure, which is related to the changes in a water absorption capacity. They reported the water absorption capacityis increasing from $300 \mathrm{~W}$ to $600 \mathrm{~W}(203.06 \pm 6.00 \%$, $236.12 \pm 0.30 \%$, and $256.23 \pm 5.00 \%$ respectively), while their dietary fiber contents were only slightly different. They also observed the compression of cellular appearance in MWG-dried sample at $600 \mathrm{~W}$.

Sangnark \& Noomhorm, (2003) reported that particle size reduction of dietary fibers has been associated with a lower ability to retain water and a lower oil binding capacity. Lario et al. (2004) and Mohammad et al. (2015) reported that the high WHC of fiber concentrate could be used as a functional ingredient to avoid syneresis, modification of texture and viscosity and reduce calories of food formulations.

The reduction of water absorption capacity by both treatments could be as a result of hydrothermal treatment which blocked the tissue pores, thereby hindering water slippage and retention (Enujiugha et al., 2012).

From Table 1, it can be seen that the oil absorption capacity is inversely proportional to the water absorption capacity. This makes sense. The ability of water and oil retention to respond to the structure of protein and polysaccharide macromolecules; The interactions between the water and the constituents are established at the level of acid groups and amine groups present in the polysaccharides or at the level of the uncharged polar groups capable of forming hydrogen bonds with water, while the groups that are apolar in character Can contribute to the structure of the water in their environment. According to Cloutour (1995), heat treatments such as microwave grill drying can alter the polysaccharide and protein content and consequently the water and oil absorption capacity.

It is noted that the capacity of water retention is clearly higher than that of the oil. This is explained by the abundance of the hydrophilic groups by adding to the hydrophobic groups, the Russian olive of which is rich in polysaccharides (pectins $1.43 \%$ and cellulose $3.92 \%$ ) and low in lipid (0.55\%) (Saadoudi, 2008; Ferhat, 2008).

\section{d) Solubility}

Solubility is an important characteristic for powdered ingredients that will be incorporated into dry mixes that must be reconstituted. To satisfy the normality assumption during the statistical analysis. The average solubility values for the Russian olive powder is Table 1. The samples dried by microwave-grill at $300 \mathrm{~W}$ had the highest average percentage of solubility $(66.00 \pm 0.11 \%)$.

In general, Russian olive components such as pectin and sugars are soluble in water, while proteins and lipids are readily soluble in acidic solutions diluted below $\mathrm{pH} 6(\mathrm{pH} 4)$, which explains the use of Acetic acid in this technique (a 1\% acetic solution is equivalent to $\mathrm{pH} 4$ ).

According to Table 1, the solubility of dried by microwave grill at different powers is acceptable without significant difference $(\geq 50 \%)$. The solubility of the macromolecules is influenced by several parameters $(\mathrm{pH}$, ionic strength, drying, concentration, temperature, etc.).

Linden and Lorient (1994) show that the property of solubility has major consequences on other functional properties (Emulsification, gelling). On the other hand, depending on the results obtained, the microwave grill drying does not have a negative effect; On the other hand, it retains this property. As a result, the other properties will be more or less conserved. 


\section{e) Emulsion activity (EA) and emulsion stability (ES)}

Table 1 shows the emulsifying capacity and the stability of emulsions Russian olive dried by microwave grill at different powers. Good capacity is observed for all samples (over $30 \%$ ). Precisely the best capacity is given for the power $300 \mathrm{~W}(62.32 \pm 0.01 \%)$.

Drying by microwave grill at different power (300,450 and $600 \mathrm{~W})$ decreased caused significant $(p<0.05)$ decrease in emulsion capacity of Russian olive berry when compared with the non-dried (control) samples. Drying by microwave grill at different power $(300,450$ and $600 \mathrm{~W}$ ) decreased emulsion capacity Russian olive berry. The decrease in emulsion property may be attributed to protein aggregation as well as surface hydrophobicity and change the characteristics, which affect emulsifying properties in different ways (Cheftel et al., 1985; Enujiugha et al., 2012).

Firstly, these results show that the applied power has an effect on this property, a moderate assay power (300W) is sufficient to have a good emulsion. On the other hand, drying by microwave, the grill does not have a dramatic effect negative vis-à-vis the emulsifying capacity. Drying by microwave grill at different power (300,450 and $600 \mathrm{~W})$ decreased emulsion capacity Russian olive berry

Emulsion capacity denotes the maximum amount of oil that can be emulsified by protein dispersion. The high emulsion capacity could be as a result of high content of free fatty acid which leads to increased oil absorption (Ihekoronye \& Ngoddy, 1985; Enujiugha et al., 2012).

The emulsifying properties are due to the reduction of inter-facial trying among the hydrophilic groups are hydrophobic groups, they are often linked to the protein solubility in water (Alain \& Roudot, 2001; Chandi \& Sogi, 2006). According to Table 1 excellent emulsion stability can be seen $(>60 \%)$ for all dried Russian olive by microwave grill at different powers nevertheless dried Russian olive at (600, 450 and $300 \mathrm{~W}$ respectively $(60 \pm 0.09,76.32 \pm 0.00$ and $64.61 \pm 0.01 \%)$.

\section{f) Foaming properties}

The results gathered in Table 1 show that non-foam for Russian olive raw and dried by microwave grill at different powers. According to Lorient et al. (1988), the formation of foams is based on the presence of proteins in quantity and quality, thus the low Russian olive protein content $(0.29 \%)$ (Abdeddaim, 2016) is insufficient to form stable foam. The shape, size, concentration, and hydrophobicity of the particles have been identified as the main factors in the formation of foams.

\section{g) Viscosity} (Table 1).

In general, the process drying resulted in a decrease viscosity of Russian olive viscosity

In our study, the viscosity of Russian olive in microwave-grill at different power ranged from 1.17 to 1.45 MPa.s. Viscosity, which is the desired parameter, is one of the qualities that characterize the flow behavior. It is a measure of the ability of the fluid to resist movement when shear stress is applied. All data show that viscosity generally decreases with drying techniques with increasing microwave grill power.

Significant changes in viscosity may be due to the significant impact of the process dryingon the biochemical composition Russian olive fruit. As also explained by Simas-Tosin et al. (2010), the presence of oligosaccharides with free reducing functions, phenolic compounds and inorganic salts and polysaccharides in the structure of the Russian olive fruit. The effect of drying on the polysaccharide viscosity of Russian olive fruit could be due to the different proportions of soluble materials compared to insoluble materials.

\section{h) $\mathrm{pH}$}

The average $\mathrm{pH}$ value of the raw berry Russian olive was $5.22 \pm 0.00$ which is within the acceptable range of $\mathrm{pH}$ (5.21-5.22) for Russians olive. The average $\mathrm{pH}$ values for the 
Russian olive powder dried using microwave-grill-drying at three different powers (300, 450 and $600 \mathrm{~W}$ ) are shown in Table 1.

Generally, the recorded $\mathrm{pH}$ is acid at the vicinity of 5 ; This is explained by the presence of free organic acids in the Russian olive (Sahan et al., 2015) such as malic acid $(0.67 \mathrm{mg} / 100 \mathrm{~g})$, oxalic acid $(0.08 \mathrm{mg} / 100 \mathrm{~g})$, ascorbic acid $(0,08 \mathrm{mg} / 100 \mathrm{~g})$, acetic acid $(0.52 \mathrm{mg} / 100 \mathrm{~g})$, citric acid $(0.59 \mathrm{mg} / 100 \mathrm{~g})$, tartaric acid $(0.52 \mathrm{mg} / 100 \mathrm{~g})$ and formic acid $(0.05 \mathrm{mg} / 100 \mathrm{~g})$.

\section{i) Total soluble solid (TSS)}

Significant changes in TSS after microwave drying were obtained due to variation power level. Decreased moisture content in fruits is generally accompanied by an increased percentage of TSS since TSS is the main component of dry matter (Malundo et al., 1995). Thus, the value of TSS is significantly $(p<0.05)$ decreased after drying (Table 1$)$. This decrease was compared to fresh fruit (42.4 ${ }^{\circ}$ Brix). Although there is a significant difference in the TSS value between the drying power levels, the value decreased with increasing power $300 \mathrm{~W}\left(1.17^{\circ}\right.$ Brix), then increased to $450 \mathrm{~W}$ ( $1.45^{\circ}$ Brix) then decreased to $600 \mathrm{~W}$ (1.29 ${ }^{\circ}$ Brix).According to our results, we found that the temperature and the treatment time had no effect on $\mathrm{pH}$ and ${ }^{\circ}$ Brix.

\section{j) Gelation properties}

The gelation concentration for Russian olive fruit raw and dried is shown in Table 2. It formed a weak gel at $2 \%$, strong gel at 16 and $20 \%$ and very strong gel.

Table 2 Gelation capacity (\%) of dried Russian olive in microwave grill at different power.

\begin{tabular}{ccccccc}
\hline Parameters & \multicolumn{5}{c}{ Gelation Capacity - Concentrations (\%) } \\
\cline { 2 - 7 } & 2 & 4 & 8 & 12 & 16 & 20 \\
\hline Fresh fruit & $13.63 \pm 0.03^{\mathrm{s}}$ & $18.18 \pm 0.01^{\mathrm{r}}$ & $36.36 \pm 0.01^{\mathrm{k}}$ & $54.74 \pm 0.01^{\mathrm{e}}$ & $81.71 \pm 0.01^{\mathrm{b}}$ & $100 \pm 0.00^{\mathrm{a}}$ \\
$300 \mathrm{~W}$ & $28.81 \pm 0.01^{\mathrm{o}}$ & $30,72 \pm 0.01^{\mathrm{h}}$ & $46.36 \pm 0.01^{\mathrm{j}}$ & $54.45 \pm 0.01^{\mathrm{g}}$ & $72.09 \pm 0.01^{\mathrm{d}}$ & $100 \pm 0.00^{\mathrm{a}}$ \\
$450 \mathrm{~W}$ & $27.27 \pm 0.00^{\mathrm{q}}$ & $31.2 \pm 0.01^{\mathrm{m}}$ & $48.81 \pm 0.01^{\mathrm{i}}$ & $54 / 45 \pm 0.01^{\mathrm{g}}$ & $72.09 \pm 0.01^{\mathrm{d}}$ & $100 \pm 0.00^{\mathrm{a}}$ \\
$600 \mathrm{~W}$ & $28.18 \pm 0.01^{\mathrm{p}}$ & $33.18 \pm 0.01^{\mathrm{l}}$ & $50.36 \pm 0.01^{\mathrm{h}}$ & $56.45 \pm 0.01^{\dagger}$ & $79.43 \pm 0.01^{\mathrm{c}}$ & $80 \pm 0.00^{\mathrm{b}}$
\end{tabular}

a, b, c, d...: In each column, means followed by a different letter are significantly different at the threshold of $\mathrm{p}<0.05$ (Method of Newman and Keuls).

The least gelation capacity results for microwave grill at 300 Wdried Russian olive is $2 \%$, and microwaved grill at $600 \mathrm{~W}$ samples ranged from $12 \%$ to $16 \%$. The gel-forming ability is reported to be influenced by the nature of the protein in the sample as well as their interaction during heat treatment (Enujiugha et al., 2012).

According to Table 2, the gelling power for the apple dried at 300 and $450 \mathrm{~W}$ and for the concentrations 16 and $20 \%$ is excellent it reaches $100 \%$, these results are explained by the richness of Russian olive in (pectins 1.43\% and cellulose 3.92\%) (Saadoudi, 2008).

In general, the concentration expresses the percentage of the gelling agents (proteins, polysaccharides, etc.), a proportional increase in the gelling power with the increase of the concentration, the better is the gelating ability of the protein ingredient (Akintayo, et al 1999). Variations in gelling properties may be ascribed to the ratios of different constituents, such as proteins, carbohydrates, and lipids (Maninder, Sandhu \& Sinth, 2007).

It is incorporated into food products such as creams, soups, puddings, pie fillings and many sauces in viscosity (Osman, 1967).

\section{CONCLUSION}

The kinetics of the dehydration of Russian olive fruit shows that microwave-grill- drying time is short in supply to other drying methods. This reveals the economic importance of dehydration by microwave of the fruits of the Russian olive.

In the drying process, power and long exposure times contribute significantly to the decreasing of emulsifying property content present in the Russian olive fruit. At 600W occurs its lowest decreasing.

The effect microwave-grill-drying at different level (300, 450 and $600 \mathrm{~W})$ on the functional Journal of Bioenergy and Food Science. Vol.7: e2752019JBFS, 2020 
properties of Russian olive fruit has a relatively low water absorption capacity compared to Russian olive fruit raw.

The values of the functional properties vary according to the powers used during microwave-grill-drying. Higher values of WAC, OAC, solubility and emulsifying power, emulsifier stability and gelation are found in Russain olive fruit dried by microwave-grill-drying at $450 \mathrm{~W}$.

These results show the important role of this fruit dried by microwave-grill-drying in the food industry, such as the manufacture of beverages on the basis of solubility and its ability to retain water, the manufacture of jellies and creams for its ability it's related to emulsifying and gelling, and any other applications, especially in confectionery and pastry.

\section{REFERENCES}

Abdeddaim, M. (2016). Etude de la composition biochimique des fruits de cinq espèces végétales présentes dans la région des aurès en vue de leur utilisation alimentaire ou pharmacologique (celtis australis L, crataegus azarolus $\mathrm{L}$, crataegus monogyna $\mathrm{J}$, elaeagnus angustifolia $\mathrm{L}$, et zizyphus lotus L). Thèse de doctorat. Université de Sétif, 174p.

AFNOR. (1982). Produits dérivés des fruits et légumes-jus de fruits. Détermination de $\mathrm{pH}$, Association française de normalisation. (Ed). AFNOR, Paris, $325 \mathrm{p}$.

Ahmediani, A., Hosseiny, J., \& Semnanian, S.L. (2000). Antinociceptive and anti-inflammatory effects of Elaeagnus angustifolia fruit extracts. Journal of Ethnopharmacology, 72, 287-292. https://doi.org/10.1016/S0378-8741(00)00222-1

Akbolat, D., Ertekin, C., Menges, H.O., Guzel, E., \& Ekinci, K. (2008). Physical and nutritional properties of oleaster (Elaeagnus angustifolia L.) growing in Turkey. Asian Journal of Chemistry, 20, 2358-2366.

Akintayo, E.T., Oshodi, A.A. \& Esuoso, K.O. (1999). Effects of $\mathrm{NaCl}$, ionic strength and $\mathrm{pH}$ on the foaming and gelation of pigeon pea (Cajanus cajan) protein concentrates. Food Chemistry, 66, 51-56. https://doi.org/10.1016/S0308-8146(98)00155-1

Alain, L., \& Roudot, C. (2001).Rhéologie et analyse de texture des aliments. Compagns Francaise (Ed). Paris, 152p.

Amadou, I., Amza, T., Foh, M.B.K., Kamara, M.T., \& Le, G.W. (2010) Influence of Lactobacillus plantarum Lp6 Fermentation on the Functional Properties of Soybean Protein Meal. Emirates Journal of Food and Agriculture, 22, 456-465. https://doi.org/10.9755/ejfa.v22i6.4663

Anon. (1995).Contrôle de qualité des products alimentaires, méthodes d'analyses officielles, AFNOR-DGCCRF, Paris, Fr, $416 \mathrm{p}$.

Ayaz, F.A, \& Bertoft, E. (2001). Sugar and phenolic acid composition of stored commercial oleaster fruits. Journal of Food Composition and Analysis, 14, 505-511. https://doi.org/10.1006/jfca.2001.1004

Baytop, T.(1984). Treatment with Plants in Turkey (Past and Present). Number: 40, pp. 260. Istanbul, Turkey: Pharmacy Faculty, Istanbul University Publication Number: 3255.

Boudraa, S., Hambaba, L., Zidani, S., \& Boudraa, H. (2010). Mineral and vitamin composition of fruits of five underexploited species in Algeria: Celtis australis L., Crataegus azarolus L., Crataegus monogyna Jacq., Elaeagnus Angustifolia. And Zizyphus lotus L. Fruits, $65,75-84$. https://doi.org/10.1051/fruits/20010003

Çakmakçı, S., Topdaş, E.F., Kalın, P., Han, H., Şekerci, P., P. Köse, L., \& Gülçin, İ. (2014). Antioxidant capacity and functionality of oleaster (Elaeagnus angustifolia L.) flour and crust in a new kind of fruity ice cream. International Journal of Food Science \& Technology, 50(2), 472-481. https://doi.org/10.1111/ijfs. 12637 
Cansev, A., Sahan, Y., Celik, G., Taskesen, S., \& Ozbey, H. (2011).Chemical properties and antioxidant capacity of Elaeagnus angustifolia L. fruits. Asian Journal of Chemistry, 23, 26612665.

Chandi, G.K., \& Sogi, D.S. (2006). Functional properties of rice bran protein concentrate. Journal of Food Engineering, 79, 592-597. https://doi.org/10.1016/j.jfoodeng.2006.02.018

Changrue, V. (2006). Hybrid (osmotic, microwave-vacuum) drying of strawberries and carrots. A thesis submitted to McGill University in partial fulfillment of the requirements for the degree ofDoctor of Philosophy, Montreal, Quebec, Canada.

Cheftel, J.C.,Cuq, J.L., \& Lorient, D. (1985). Food Chemistry (2nded.), Marcel Dekker, New York. 29.

Cloutour, F. (1995). Caractéristiques de fibres alimentaires: influence sur la fermentation in vitro par la flore digestive alimentaire. Thèse de doctorat, Université de Nantes, $123 p$.

Coffman, C.W., \& Garcia V.V. (1977). Functional properties and amino acid content of protein isolate from mung bean flour. Journal of Food Technology, 12, 473-484. https://doi.org/10.1111/j.1365-2621.1977.tb00132.x

Durmaz, E. (2012). Microwave Extraction of Phenolic Compounds from Caper and Oleaster. Ankara, Turkey: Master of Science in Food Engineering Department, Middle East Technical University.

Enujiugha, V.N., Badejo, A.A., Iyiola, S.O., \& Oluwamukomi M.O. (2003). Effect of germination on the nutritional and functional properties of African oil bean (Pentaclethra macrophylla Benth) seed flour. Journal Food Agriculure and Environnoment, 1, 72-75.

Enujiugha, V.N., Olotu, I.O., \& Malomo, S.A. (2012). The Effect of $y$-irradiation and Cooking on the Physicochemical Properties of African Oil Bean Seed (Pentaclethra macrophylla benth) and Its Oil Extract. Journal of Food Research, 1(2), 189-201. https://doi.org/10.1111/jfpp.12179

Ferhat, R. (2008). Étude de la fraction lipidique et la composition en acides gras des fruits de: Celtis australus L., Crataegus azarolus L., Cratagus monogyna Jacq., Elaeagnus angustifolia L et Ziziphus lotus L. Mémoire de Magister. Université El Hadj-Lakhder. Batna, 102p.

Fernandez-Kim, S.O. (2004). Physicochemical and functional properties of crawfish chitosan as affected by different processing protocols.Master Thesis of Science. Louisiana State University, 99p.

Gulcu, S., \& Celik-Uysal, S. (2010). Kus igdesi'nde (Elaeagnus Angustifolia L.) yetistirme sıklıgının fidan morfolojik ozellikleri neetkisi. SDU Faculty of Forestry Journal, 2, 74-81. http:/dx.doi.org/10.17568/ogmod.331301

Ihekoronye, A.I., \& Ngoddy, P.O. (1985). Food Carbohydrates. In: Integrated Food Science and Technology for the tropics Macmillan publisher, London. pp. 10-19.

Journal d'Agriculture Tropicale et de Botanique Appliquée. (1958). Les méthodes d'enquête en ethnobotanique: Comment mettre en évidence les taxonomies indigenes. Paris. 15(7-8), 297324. https://doi.org/10.3406/jatba.1968.2992

Kisambira, A., Muyonga, J., Byaruhanga, Y., Tukamuhabwa, P., Tumwegamire, S., \& Grüneberg, W. (2015) Composition and Functional Properties of Yam Bean (Pachyrhizus spp.). Seed Flour. Food and Nutrition Sciences, 6, 736-746. https://doi.org/10.4236/fns.2015.68076

Kostaropoulos, A.E., \& Saravacos, G.D.(1995). Microwave pretreatment for sun-dried raisins, Journal of Food Sciences, 60 ,344-347. https://doi.org/10.1111/j.1365-2621.1995.tb05669.x 
Kwok, B.H.L., Hu, C., Durance, T., \& Kitts, D.D. (2004). Dehydration Techniques Affect Phytochemical Contents and Free Radical Scavenging Activities of Saskatoon berries (Amelanchier alnifolia Nutt). Journal of Food Science, 69, 122-126. https://doi.org/10.1111/j.1365-2621.2004.tb13381.x

Lario, Y., Sendra, E., García-Pérez, J., Fuentes, C., Sayas-Barberá, E., Fernández-López, J., \& Perez-Alvarez, J.A. (2004). Preparation of high dietary fiber powder from lemon juice byproducts. Innovative Food Science Emerging Technology, 5, 113-117. https://doi.org/10.1016/j.ifset.2003.08.001

Linden, L., \& Lorient, D. (1994). Biochimie agro-industrielle-Valorisation alimentaire de la production agricole. (ED) Masson. Paris. Milan. Barcelone, 359p.

Lorient, D., Colas, B., \& Le meste, M. (1988). Propriétés fonctionnelles des macromolécules alimentaires. The notebooks of the ENS.BANA.N ${ }^{\circ}$ 6. (ED) Tec and doc- Lavoisier. Paris, 268p.

Malundo, T.M.M., Shewfelt, R.L., \& Scott, J.W. (1995).Flavor quality of fresh tomato (Lycopersicone sculentum Mill.) as affected by sugar and acid levels. Postharvest Biology Technology, 6, 103-110. https://doi.org/10.1016/0925-5214(94)00052-T

Mohammad, A.A., Yousif, E.I., Yaseen, A.A., Gdallah, M.G., Shouk, A.A., \& Abdel Fatah, A.A. (2015). Physico-Chemical and Functional Properties of Nano and Fermented-Nano Powders of Some Food Plant By-products. Current Science International, 4(4), 503-514. https://doi.org/10.1016/j.foodchem.2005.07.016

Movagharnejad, K., Vahdatkhoram, F., \& Nanvakenari, S.J. (2019). Optimization of microwave and infrared drying process of nettle leaves using design of experiments. Journal of Thermal Analysis and Calorimetry, 135(3), 1677-1685. https://doi.org/10.1007/s10973-018-7511-5

Neto, V.Q., Narain, N., Silvia, J.B., \& Bora, P.S. (2001). Functional properties of raw and heatprocessed cashew nut (Anarcardium occidentale L.) kernel protein isolate. Nahrung, 45, 258262. https://doi.org/10.1002/1521-3803(20010801)45:4<258::AID-FOOD258>3.0.CO;2-3

Odedeji, J.O., \& Adeleke, R. (2010). Pasting characteristics of wheat and sweet potato flour blends. Pakistan Journal of Nutrition, 9(6), 555-557. https://doi.org/10.3923/pjn.2010.555.557

Osman, E.M., (1967). Starch in the Food Industry. Academic Press, New York, pp: 163-193.

Phillips, R.D., Chinnan, M.S., Branch, A.L., Miller, J., \& Mc-Watters, K.H. (1988). Effects of pretreatment on functional and nutritional properties of cow pea meal. Journal of Food Science, 53(3), 805-809. https://doi.org/10.1111/j.1365-2621.1988.tb08959.x

Princewill-Ogbonna, I., \& Ezembaukwu, N. (2015). Effect of various processing methods on the pasting and functional properties of Aerial yam (Dioscorea bulbifera) flour. British Journal of Applied Science and Technology, 9(5), 517-526. https://doi.org/10.9734/BJAST/2015/17915

Robertson, J.A., \& Eastwood, M.A. (1981). An examination of factors which may affect the water holding capacity of dietary fiber. British Journal of Nutrition, 45, 83-88. https://doi.org/10.1079/BJN19810079

Saadoudi, M. (2008). Etude de la fraction glucidique des fruits de Celtis australus L., Crataegus azarolus L., Cratagus monogyna Jacq., Elaeagnus angustifolia L et Ziziphus lotus L. Mémoire de Magister. Université El Hadj-Lakhder, Batna, 98p.

Sahan, Y., Gocmen, D., Cansev, A., Celik, G., \& Aydin, D.(2015).Chemical and techno-functional properties of flours from peeled and unpeeled oleaster (Elaeagnus angustifoliaL.). Journal of Applied Botany and Food Quality, 88, 34-41. https://doi.org/10.5073/JABFQ.2015.088.007

Sandhu, K.S., \& Singh, N. (2007). Comparative study of the functional, thermal and pasting Journal of Bioenergy and Food Science. Vol.7: e2752019JBFS, 2020 
properties of flours from different field pea (Pisum sativum L.) and pigeon pea (Cajanus cajan $\begin{array}{llll}\text { L.) cultivars. } \quad \text { Food } \quad \text { Chemistry, } & \text { 104(1), }\end{array}$ https://doi.org/10.1016/j.foodchem.2006.11.037

Sangnark, A., \& Noomhorm, A.(2003). Effect of particle sizes on functional properties of dietary fiber prepared from sugarcane bagasse. Food Chemistry, 80, 221-229. https://doi.org/10.1016/S0308-8146(02)00257-1

Simas-Tosin, F.F., Barraza, R.R., Petkowicz, C.L.O., Silveira, J.L.M., Sassaki, G.L., Santos, E.M.R., Gorin, P.A.J., \& lacomini, M. (2010). Rheological and structural characteristics of peach tree gum exudates. Food Hydrocolloids. 24, 486-493. https://doi.org/10.1016/j.foodhyd.2009.12.010 